\title{
BLOCK-NOTES MUNDIAL*
}

\author{
Anônimo
}

\begin{abstract}
Resumo: Texto anônimo publicado na revista carioca Fon-fon, em 1918. Procura afastar Nietzsche do imperialismo germânico do período. Além disso, se mostra importante por tratar da recepção francesa do pensador. Palavras-chave: Nietzsche - Alemanha - moral
\end{abstract}

Nietzsche - escreveu Remy de Gourmout - não escrevia para a Alemanha, que não compreendia as suas concepções filosóficas. Nietzsche escrevia para a humanidade. Sua influência sobre mundo só começou quando o seu pensamento, traduzido em Francês, se tornou acessível aos que participam da civilização francesa. O filósofo sabia-o bem. $O$ pensamento alemão não tem irradiação fora da Alemanha, não tem influência sobre cérebros alemães. Como ele queria, apesar disso, falar aos outros homens, mais de uma vez tentara fazer-se traduzir em francês. Não tinha outro fim as suas tentativas junto a Taine. Nietzsche só se tornou universal depois que as suas obras foram traduzidas em francês. $\mathrm{O}$ filósofo não teve participação alguma na grande loucura germânica. Ele sonhava acima do bem e do mal, e seus sonhos não eram sonhos alemães, mas sonhos de semideus. Para medir a distância que separa o seu pensamento do de Ostwald, químico e filósofo, como Nietzsche era filósofo, é preciso compreender que Nietzsche, teorista do super-homem, quer levar o indivíduo acima das leis cristãs, ao passo que Ostwald, teorista da energia, quer desenvolver a energia da

* Publicado na revista Fon-Fon. Rio de Janeiro, Fevereiro de 1918, p. 06. 
massa alemã, da dominação alemã. A ideia de Ostwald se opõe à de Nietzsche na nova Alemanha. Por sua educação, pela feição do seu espírito, inteiramente especulativo, ele pertence francamente a um período alemão em que não havia ainda nascido o verdadeiro espírito alemão, de dominação e de egoísmo nacional. Podia-se ler Nietzsche sem mesmo perceber, a não ser pela maneira nebulosa de suas frases, que era um alemão. Nietzsche era europeu, e ele mesmo se gabava disso. Uma das suas frases favoritas era esta: “Nós outros, europeus...". O filósofo está acima da ideia nacional. É-lhe preciso uma pátria mais larga e sobretudo mais livre, Zaratustra precisa de uma pátria romântica: oprimi-lo-ia a que foi criada pelas novas ideias alemãs, depois da vitória de 1870. Mas Nietzsche já tinha a sua razão morta quando essas ideias começaram a ter um desenvolvimento inesperado, quando, abandonando a civilização europeia, os alemães entraram na prisão da sua cultura nacional. Ele já não escrevia mais, e nada do que escrevera anteriormente tem o estigma do egoísmo alemão. É também ele o último alemão que pertence francamente à civilização europeia. Tem se dito, um pouco inconsideradamente, que Nietzsche tinha sido um dos educadores de Guilherme II. Guilherme, nesse caso, aproveitou muito mal as lições, porque Nietzsche prega aos homens, não a dominação sobre os seus semelhantes, mas a dominação sobre si mesmos. É de lembrar-se o perfil que ele fez do verdadeiro filósofo, do filósofo dos novos tempos, de quem exige tamanha força de alma e mesmo abnegação. É isto que ele exige também dos que querem dominar seus irmãos, e nunca, mesmo em suas páginas mais brutais, se encontra o elogio puro e simples da força. Do fato dele distinguir a moral dos senhores da moral dos escravos, não se deve concluir que ele reconheça o direito de ser senhor a quem não possui senão a força nua. Esse admirador da Renascença sabia bem quais são os elementos imponderáveis de um "condottiere", e que, para dominar os homens é preciso mais alguma coisa além da fé na sua espada. Mas os diretores da ideia alemã tomaram o hábito de atrair a si todos os escritores alemães antigos e modernos e de 
fazê-los dizer o que convém à sua tese. É bem possível que Guilherme II tenha lido Nietzsche às avessas, e que o conselho místico: "Sêde duros!", Guilherme o tenha tomado ao pé da letra, como uma incitação à crueldade. Para nós, entretanto, Nietzsche, longe de encarnar o imperialismo ou a cultura alemã, se lhe opõe nitidamente. Ele representa outra forma de civilização, a que parte dos gregos e vem ter aos franceses, ou melhor, aos europeus do século XIX. Pois, não se viu Nietzsche censurar essa mesma "Kultur", da qual se pretende que ele seja um dos mestres? Ele, que chorou com a notícia do bombardeamento de Paris, como ter-se a audácia de supor que aprovaria a destruição do Louvre?

\footnotetext{
Abstract: Anonymous text, published in the magazine Fon-Fon, Rio de Janeiro, in 1918. Want away Nietzsche's German imperialism period. In addition, is important why treat about the reception French of thinker.

Keywords: Nietzsche - Germany - moralist
} 
